\title{
Survey of Multi-Resistant Bacteria in Waste Water from the Yopougon Hospital and University Center (CHU), The Abattoir of Port-Bouët and the Lagoon Bays of the City of Abidjan (Côte d'Ivoire)
}

\author{
Wognin Affou Séraphin ${ }^{1,2 *}$, Ouattara Mohamed Baguy ${ }^{3}$, N'goran Kouamé Edouard ${ }^{2}$ \\ and Guessennd Kouadio Nathalie ${ }^{3}$ \\ ${ }^{1}$ Department of Microbiology - Biochemistry of the University Peleforo Gon Coulibaly, \\ Korhogo, Côte d'Ivoire \\ ${ }^{2}$ Department of Microbiology, Ecotoxicology and Radioecology of the Ivorian Anti-Pollution \\ Center, Abidjan, Côte d'Ivoire \\ ${ }^{3}$ Institut Pasteur, Abidjan, Côte d'Ivoire \\ *Corresponding author
}

\section{A B S T R A C T}

Keywords

Multi-resistant, effluents, abattoir, lagoon bays

Article Info

Accepted:

12 April 2021

Available Online:

10 May 2021
Antibiotic resistance has become a global concern due to their excessive use in human and veterinary medicine. The purpose of the study was to determine the level of antibiotic resistance in multi-resistant gram-negative enterobacteria and bacilli isolated from the effluents of the Port-bouët abattoir, the Yopougon Hospital and University Center, and the lagoon bays of the city of Abidjan. It was conducted over the period of January to December 2019. A total of 192 wastewater samples were collected and analyzed at the Microbiology laboratory of ivorian antipollution Center. The antibiogram was performed at the Institut Pasteur of Côte d'Ivoire. The bacteriological analysis allowed the isolation of 34 species of enterobacteria and 19 non-fermentative gram-negative bacilli with a respective predominance of Klebsiella pneumoniae (41.2\%) and Aeromonas hydrophila (42.1\%). The study also revealed high resistance rates of $50-100 \%$ to beta-lactams in enterobacteria and gram-negative bacilli with almost no resistance to imipenem. High resistance has also been observed with some quinolone antibiotics, aminoglycosides, phenicol, fosfomycin and sulfamethoxazole. The presence of multi-resistant bacteria in these effluents represents a real risk for public health.

\section{Introduction}

Antibiotic resistance has become a major concern, leading to a real awareness both nationally and internationally, especially since in recent years, the development of new antibiotic molecules has become rare (Cizman and Plankar, 2018). 
The overuse of antibiotics, both in human and veterinary medicine, or as a growth factor in animal husbandry, has led to the emergence and spread of antibiotic-resistant bacteria. The overuse of antibiotics, both in human and veterinary medicine, or as a growth promoter in animal husbandry, has led to the emergence and spread of bacteria that are multi-resistant to antibiotics (Meyer et al., 2013; Beyene and Tesega, 2014).

In addition to the hospital environment and animal husbandry, multi-resistant bacteria have now spread in the environment, and their detection in wastewater (hospital and municipal effluents), at wastewater treatment plants, in surface or ground water, and in soil is now established (Baquero et al., 2008; Rizzo et al., 2013).

Therefore, hospital and municipal effluents have been identified as potential reservoirs of multi-resistant bacteria in general and enterobacteria in particular (Tennstedt et al., 2003).

Indeed, the strong selection pressure represented by the release of large quantities of antibiotics into nature and the pollution of water by commensal enterobacteria from humans and animals are strong arguments for thinking that the environment is a reservoir of multi-resistant bacteria (Kummerer, 2004).

The problem of antimicrobial resistance increasingly tends to be seen as a global environmental issue. The commensal intestinal flora of humans, animals and the bacterial flora of hospital and municipal effluents are now considered as a potential reservoir of antibiotic-resistant bacteria and/or resistance genes, potentially transmissible to humans (Goni-Urriza et al., 2000 ; Bonnedahl et al., 2009). A public health problem then arises because humans, in the various environments in which they live, may be exposed to these multi-resistant bacteria, particularly through their activities with water (watering market gardening crops, swimming, etc.). On the other hand, their presence in the environment could lead to the transfer of resistance genes to environmental bacteria, thus causing an even greater spread of these antibiotic resistances.

The objective of this study was to contribute to the monitoring of multi-resistant gramnegative bacteria in the environment through the effluents of the municipal abattoir of PortBouët, the hospital and university center (CHU) of Yopougon and the lagoon bays of the city of Abidjan. Specifically, the aim was to (i) isolate resistant bacteria from the effluents of the Port-Bouët slaughterhouse, the Yopougon hospital and university hospital center (CHU) and the waters of the lagoon bays, (ii) study the resistance profiles of the multi-resistant strains isolated.

\section{Materials and Methods}

This was a study of the multiresistance of strains of gram-negative bacteria isolated from the effluents of the municipal abattoir of PortBouët, the CHU of Yopougon and the lagoon bays of the city of Abidjan.

The geographical coordinates of the different sampling sites (stations) in the District of Abidjan are recorded in Table 1. Each site was subject to water sampling at 0.5 meters from the surface of the water body. Thus, from January to December 2019, two campaigns of 8 waters samples were taken monthly, i.e. 16 samples per month.

The geographical coordinates of the different sampling sites (stations) in the District of Abidjan are recorded in Table I. Each site was subject to water sampling at 0.5 meters from the surface of the water body. Thus, from January to December 2019, two campaigns of 
8 waters samples were taken monthly, i.e. 16 samples per month.

A total of 192 waters samples were collected for this study and placed in a cooler containing cold accumulators and transported to the laboratory for bacteriological analysis.

The isolation and identification of multiresistant gram-negative bacteria were carried out at the microbiology laboratory of the Ivorian Anti-Pollution Center. Decimal dilutions carried out on the different water samples were used to isolate multi-resistant gram-negative bacilli on media made selective by the addition of antibiotic powder.

Drigalski agars with $4 \mathrm{mg} / \mathrm{L}$ of ceftazidime were used to isolate multi-resistant enterobacteria and non-fermenting gramnegative bacteria.

Cetrimide agars with $8 \mathrm{mg} / \mathrm{L}$ ceftazidime and $8 \mathrm{mg} / \mathrm{L}$ imipenem have been used for the detection and identification of multi-resistant bacteria of the genus Pseudomonas. The inoculation of the different agars with antibiotic was performed by spreading $0.1 \mathrm{~mL}$ of the different dilutions.

All Petri dishes were incubated at $37^{\circ} \mathrm{C}$ for 24 hours. The identification of multi-resistant Gram-negative bacilli was carried out using the Api20E gallery (Biomérieux, France) after the fresh state, the Gram stain and the catalase test.

All antibiotic susceptibility tests were performed at the laboratory of the national antibiotic reference center of the Institut Pasteur of Côte d'Ivoire. Antimicrobial susceptibility of $\beta$ extended-spectrum enterobacteria $\beta$-lactamase isolates was determined by the Bauer-Kirby disc diffusion test using antibiotic discs (Bio-Rad, France) (Bauer et al., 1996).

\section{Results and Discussion}

Microbiological analysis of the water samples analyzed revealed 34 species of Enterobacteriaceae with a predominance of Klebsiella pneumoniae species, i.e. 14 isolated species $(41.2 \%)$. On the other hand, 19 nonfermentative gram-negative bacilli were identified with a predominance observed with the 8 Aeromonas hydrophila species, i.e., $42.1 \%$ (Tables 2 and 3).

Sensitivity tests performed on isolated bacteria revealed high rates of resistance to the same families of antibiotics as ESBL enterobacteria in non-fermentative gram-negative bacilli. Most of the isolated Enterobacteriaceae were resistant to 5 families of antibiotics including the beta-lactam, quinolone, aminoglycoside, phenicol and other families (Fosfomycin, Trimethoprim/sulfamethoxazole). Concerning non-fermentative gram-negative bacilli, resistance has been observed with the families of beta-lactam antibiotics, quinolones, aminoglycosides.

The omnipresence of multi-resistant bacteria in the environment has been demonstrated worldwide (Blaak et al., 2015 ; Zhang et al., 2016). Multiresistant gram-negative bacteria, particularly BLSE enterobacteria and multiresistant non-fermentative gram-negative bacilli, have been detected in various samples of effluents from the Port-Bouët slaughterhouse, the Yopougon university hospital and the waters of the lagoon bays of Abidjan during various sampling campaigns. In Côte d'Ivoire, the hospital effluent evacuation network consists either of a pipe leading directly to the receiving environment (Ebrie lagoon), as is the case in some hospitals and universities, or it is connected to the municipal wastewater network.

The connection of the hospital effluent evacuation network to the municipal 
wastewater evacuation network could justify, in part, the presence of multi-resistant bacteria in the waters of the lagoon bays.

In the study on the isolation of broad-spectrum beta-lactamase-producing Enterobacteriaceae isolated from lagoon berries, Klebsiella pneumoniae and Escherichia coli were the most isolated bacteria. The predominance of these species had already been highlighted during a previous study carried out by (Ouattara et al., 2014) on broad-spectrum beta-lactamase-producing enterobacteria of various origins (human, animal and environmental) in Abidjan, Côte d'Ivoire. The presence of ESBLs in surface waters has been frequently demonstrated worldwide, leading to the conclusion that if bacteria in the water are able to host ESBL genes, ESBLs will be present in the population (Zurfluh et al., 2013; Blaak et al., 2015; Zhang et al., 2016; Zarfel et al., 2017). The spread of ESBLs is facilitated by the location of most ESBL genes on mobile genetic elements that allow the transmission of resistance genes to strains and species better adapted to the surface water environment. As a result, environmental bacteria can acquire resistance genes from, for example, clinically derived strains (Zurfluh et al., 2013; Blaak et al., 2015; Zhang et al., 2016; Zarfel et al., 2017).

All these findings confirm that ESBL enterobacteria, which were originally described as hospital bacteria, have spread widely in the environment. Among the multiresistant gram-negative bacilli, the Aeromonas hydrophila and Pseudomonas aeruginosa species were the most isolated. These multiresistant bacteria are heavily implicated in hospital infections. The presence of these species seems to be again related to the discharge of hospital waste water directly into the receptacle that is the Ebrié lagoon of Abidjan. In addition, Pseudomonas aeruginosa, a hydrophilic species for which hospital wastewater may be an ideal habitat (Tumeo et al., 2008). Their presence in hospital effluents has been demonstrated by several authors (Schwartz et al., 2003 ; Tumeo et al., 2008).

Overall, strains of Enterobacteriaceae have shown a high level of antibiotic resistance. This could be explained by the strong selection pressure due to the often abusive and uncontrolled use of antibiotics in both human and veterinary medicine and the presence of unmetabolized antibiotic residues in effluents. In addition, the production of ESBLs is often associated with resistance to several other antibiotics with the same genetic carriers as ESBLs (Paterson, 2006).

These are the genes for resistance to aminoglycosides (Gentamycin; Amikacin), acetylase AAC6'-Ib-cr, cotrimoxazole (SXT), and the plasmid gene for resistance to quinolones (Nalidixic acid; Ciprofloxacin), qnr (Martínez-Martínez, 2006). All isolated strains produce broad-spectrum betalactamase regardless of strain origin. All isolated BLSE strains have a very high level of resistance to $\mathrm{C} 3 \mathrm{G}$ and $\mathrm{C} 4 \mathrm{G}$. According to Winokur (2001), EBLSEs, due to their genomic characteristics, are usually resistant to $\mathrm{C} 3 \mathrm{G}$ and Aztreonam, but may be sensitive to $\mathrm{C} 4 \mathrm{G}$ and carbapenems, beta-lactam antibiotics depending on the resistance genes they host.

In addition to the antibiotics used to characterize the EBLSE phenotype, high resistance of the strains was observed to Amoxicillin + clavulanic acid. A level of resistance of $50 \%$ to Cefoxitin was also observed. These levels could be explained by the simultaneous synthesis of AmpC-type cephalosporinases, which confers EBLSE resistance to clavulanic acid.

The resistance of EBLSEs to $\mathrm{C} 3 \mathrm{G}$ reflects the 
extensive use of $\mathrm{C} 3 \mathrm{G}$ and Aztreonam in human therapeutics. Indeed, several antibiotics including Carbapenems, Cefoxitin, C3G and clavulanic acid are inducers of betalactamases. C3Gs present a very high selection risk because they eliminate wild (susceptible) bacteria and bring out those that hyperproduce high-level cephalosporinase. The ESBL enterobacteria strains isolated were also resistant to fosfomycin, an antibiotic used in human medicine for the treatment of ESBL enterobacteria infections (Winokur, 2001).

Table.1 Geographic coordinates of sampling stations

\begin{tabular}{|l|c|}
\hline Stations & \multicolumn{1}{|c|}{ GPS coordinates } \\
\hline Yopougon Béago & $05^{\circ} 18^{\prime} 316 \mathrm{~N} ; 04^{\circ} 03^{\prime} 917 \mathrm{~W}$ \\
\hline Attécoubé Boribana & $05^{\circ} 19^{\prime} 691 \mathrm{~N} ; 04^{\circ} 01^{\prime} 969 \mathrm{~W}$ \\
\hline Port bouët Zimbaboué & $05^{\circ} 16^{\prime} 752 \mathrm{~N} ; 04^{\circ} 00^{\prime} 098 \mathrm{~W}$ \\
\hline Port bouet Abattoir & $05^{\circ} 15^{\prime} 492 \mathrm{~N} ; 03^{\circ} 58^{\prime} 132 \mathrm{~W}$ \\
\hline Koumassi digue & $05^{\circ} 16^{\prime} 457 \mathrm{~N} 03^{\circ} 55^{\prime} 801 \mathrm{~W}$ \\
\hline Marcory Biafra & $05^{\circ} 19^{\prime} 677 \mathrm{~N} ; 04^{\circ} 00^{\prime} 833 \mathrm{~W}$ \\
\hline Cocody M'badon & $05^{\circ} 19^{\prime} 955 \mathrm{~N} ; 03^{\circ} 55^{\prime} 737 \mathrm{~W}$ \\
\hline Yopougon Centre Hospitalier et Universitaire & $05^{\circ} 21^{\prime} 207 \mathrm{~N} 04^{\circ} 05^{\prime} 049 \mathrm{~W}$ \\
\hline
\end{tabular}

Table.2 Frequency of Isolated Enterobacteriaceae Species

\begin{tabular}{|c|c|c|}
\hline Enterobacteriaceae & Numbers & Percentage (\%) \\
\hline Klebsiella pneumoniae & 14 & 41,2 \\
\hline Escherichia coli & 7 & 20,6 \\
\hline Enterobacter aerogenes & 4 & 11,8 \\
\hline Citrobacter freundii & 3 & 8,8 \\
\hline Serratia liquefaciens & 3 & 8,8 \\
\hline Enterobacter cloacae & 2 & 5,9 \\
\hline Raoutella ornithinolytica & 1 & 2,9 \\
\hline Total & $\mathbf{3 4}$ & $\mathbf{1 0 0}$ \\
\hline
\end{tabular}

Table.3 Frequency of Isolated Gram-Negative Bacilli

\begin{tabular}{|l|c|c|}
\hline Non-enterobacteria & Numbers & Percentage (\%) \\
\hline Aeromonas hydrophila & 08 & 42,1 \\
\hline Pseudomonas aeruginosa & 04 & 21,1 \\
\hline Vibrio fluvialis & 04 & 21,1 \\
\hline Pseudomonas fluorescens & 02 & 10,5 \\
\hline Burkholderia cepacia & 01 & 5,3 \\
\hline \multicolumn{1}{|c|}{ Total } & $\mathbf{1 9}$ & $\mathbf{1 0 0}$ \\
\hline
\end{tabular}


Table.4 Antibiotic Resistance rates of Enterobacteriaceae Isolated

\begin{tabular}{|c|c|c|c|c|c|c|c|}
\hline \multicolumn{8}{|c|}{ Number of resistant strains $(\mathrm{I}+\mathrm{R} \%)$} \\
\hline & $\begin{array}{l}\text { K. pneumoniae } \\
(\mathrm{N}=14)\end{array}$ & $\begin{array}{l}\text { E. coli } \\
(\mathrm{N}=7)\end{array}$ & $\begin{array}{c}E . \\
\text { aerogenes } \\
(\mathrm{N}=4)\end{array}$ & $\begin{array}{l}\text { C. freundii } \\
\qquad(\mathrm{N}=3)\end{array}$ & $\begin{array}{l}\text { S. liquefaciens } \\
\qquad(\mathrm{N}=3)\end{array}$ & $\begin{array}{l}\text { E. cloacae } \\
(\mathrm{N}=1)\end{array}$ & $\begin{array}{l}\text { R.ornithinolytica } \\
\qquad(\mathrm{N}=1)\end{array}$ \\
\hline \multicolumn{8}{|l|}{ Bêta-lactamines } \\
\hline $\begin{array}{l}\text { Amoxicilline+acide } \\
\text { clavulanique* }\end{array}$ & $14(100)$ & $7(100)$ & $4(100)$ & $3(100)$ & $3(100)$ & $2(100)$ & $1(100)$ \\
\hline Ceftazidime* & $14(100)$ & $7(100)$ & $4(100)$ & $3(100)$ & $3(100)$ & $2(100)$ & $1(100)$ \\
\hline Ceftriaxone * & $14(100)$ & $7(100)$ & $4(100)$ & $3(100)$ & $3(100)$ & $2(100)$ & $1(100)$ \\
\hline Cefepime* & $14(100)$ & $7(100)$ & $4(100)$ & $3(100)$ & $3(100)$ & $2(100)$ & $1(100)$ \\
\hline Cefotaxime* & $14(100)$ & $7(100)$ & $4(100)$ & $3(100)$ & $3(100)$ & $2(100)$ & $1(100)$ \\
\hline Cefoxitine & $7(50)$ & $0(0)$ & $2(50)$ & $3(100)$ & $3(100)$ & $2(100)$ & $1(100)$ \\
\hline Imipénème & $0(0)$ & $0(0)$ & $0(0)$ & $0(0)$ & $0(0)$ & $0(0)$ & $0(0)$ \\
\hline \multicolumn{8}{|l|}{ Quinolones } \\
\hline Acide nalidixique & $9(64,3)$ & $7(100)$ & $2(50)$ & $3(100)$ & $3(100)$ & $2(100)$ & $1(100)$ \\
\hline Ciprofloxacine & $9(64,3)$ & $4(50)$ & $2(50)$ & $3(100)$ & $3(100)$ & $2(100)$ & $1(100)$ \\
\hline Levofloxacine & $9(64,3)$ & $4(50)$ & $2(50)$ & $3(100)$ & $3(100)$ & $2(100)$ & $1(100)$ \\
\hline \multicolumn{8}{|l|}{ Aminosides } \\
\hline Gentamicine & $4(35,7)$ & $0(0)$ & $2(50)$ & $3(100)$ & $3(100)$ & $0(0)$ & $1(100)$ \\
\hline Tobramycine & & $0(0)$ & $2(50)$ & $3(100)$ & $3(100)$ & $0(0)$ & $1(100)$ \\
\hline Amikacine & $0(0)$ & $0(0)$ & $0(0)$ & $0(0)$ & $0(0)$ & $0(0)$ & $0(0)$ \\
\hline \multicolumn{8}{|l|}{ Phénicolés } \\
\hline Chloramphénicol & $4(35,7)$ & $0(0)$ & $4(100)$ & $3(100)$ & $0(0)$ & $2(100)$ & $0(0)$ \\
\hline \multicolumn{8}{|l|}{ Autres familles } \\
\hline Fosfomycine & $4(35,7)$ & $0(0)$ & $2(50)$ & $0(0)$ & $0(0)$ & $2(100)$ & $0(0)$ \\
\hline $\begin{array}{c}\text { Trimethoprime/sulfamethox } \\
\text { azole }\end{array}$ & $9(64,3)$ & $7(100)$ & $2(50)$ & $3(100)$ & $3(100)$ & $2(100)$ & $1(100)$ \\
\hline
\end{tabular}


Table.5 Antibiotic resistance rates of isolated gram-negative non-fermentative bacilli

\begin{tabular}{|c|c|c|c|c|c|}
\hline \multicolumn{6}{|c|}{ Number of resistant strains $(I+R \%)$} \\
\hline Antibiotics & $\begin{array}{l}\text { Aeromonas hydrophila } \\
\qquad(\mathrm{N}=8)\end{array}$ & $\begin{array}{l}\text { Pseudomanas } \\
\text { aeruginosa } \\
(\mathrm{N}=4)\end{array}$ & $\begin{array}{l}\text { Vibrio fluvialis } \\
\qquad(\mathrm{N}=4)\end{array}$ & $\begin{array}{l}\text { Pseudomanas } \\
\text { fluorescens } \\
(\mathrm{N}=2)\end{array}$ & $\begin{array}{c}\text { Burkholderia } \\
\text { cepacia } \\
(\mathrm{N}=1)\end{array}$ \\
\hline \multicolumn{6}{|l|}{ Bêta-lactamines } \\
\hline $\begin{array}{l}\text { Ticarcilline+acide } \\
\text { clavulanique* }\end{array}$ & $8(100)$ & $4(100)$ & $4(100)$ & $2(100)$ & $1(100)$ \\
\hline Ceftazidime* & $6(75)$ & $4(100)$ & $4(100)$ & $2(100)$ & $1(100)$ \\
\hline Ceftriaxone * & $6(75)$ & $4(100)$ & $4(100)$ & $2(100)$ & $1(100)$ \\
\hline Cefepime* & $4(50)$ & $2(50)$ & $4(100)$ & $2(100)$ & $1(100)$ \\
\hline Cefotaxime* & $6(75)$ & $4(100)$ & $4(100)$ & $2(100)$ & $1(100)$ \\
\hline Imipénème & $8(100)$ & $0(0)$ & $4(100)$ & $2(100)$ & $1(100)$ \\
\hline \multicolumn{6}{|l|}{ Quinolones } \\
\hline Ciprofloxacine & $4(50)$ & $2(50)$ & $4(100)$ & $0(0)$ & $1(100)$ \\
\hline Levofloxacine & $4(50)$ & $2(50)$ & $4(100)$ & $0(0)$ & $0(0)$ \\
\hline \multicolumn{6}{|l|}{ Aminosides } \\
\hline Tobramycine & $2(25)$ & $2(50)$ & $4(100)$ & $0(0)$ & $1(100)$ \\
\hline Gentamicine & $6(75)$ & $0(0)$ & $0(0)$ & $0(0)$ & $0(0)$ \\
\hline Netimicine & $6(75)$ & $0(0)$ & $0(0)$ & $0(0)$ & $0(0)$ \\
\hline Amikacine & $6(75)$ & $0(0)$ & $0(0)$ & $0(0)$ & $0(0)$ \\
\hline
\end{tabular}


The observation of high levels of resistance to the same antibiotics as ESBL in nonfermentative Gram-negative bacilli could also be explained by the presence of numerous resistance genes on large plasmids that could be hosted by bacteria. Indeed, many resistance genes have migrated from bacteria naturally carrying these genes to environmental bacteria such as Pseudomonas. In addition, many phenomena of exchange of resistance genes such as conjugation, transformation allow bacteria in the environment to acquire many resistance genes in order to ensure their survival. The very high rate of resistance observed to carbapenems in non-fermentative Gram-negative bacilli is thought to be related to the presence of certain carbapenem resistance genes such as IMP, VIM and SIM genes.

The present study highlighted the presence of multi-resistant bacteria (BLSE enterobacteria and non-fermenting gram bacilli) in wastewater and surface water (lagoon water). Particularly high rates of resistance to often major antibiotics were observed and in general, isolated ESBL enterobacteria are resistant not only to several families of antibiotics but also to several antibiotics of the same family. This observation once again raises the issue of the impact of the discharge of certain untreated effluents such as hospital and municipal effluents directly into the lagoon environment. The presence of these multi-resistant bacteria would represent a major public health problem.

\section{References}

Baquero, F., Martinez, J. L. and Canton R., 2008. Antibiotics and Antibiotic Resistance in Water Environments. Current Opinion in Biotechnology, 19: 260-265. doi: 10.1016/j.copbio.2008.05.006.

Bauer, A. W., Kirby, W. M. M., Sherris, J. C. and Turk, M. 1966. Antibiotic susceptibility testing by a standardized single disc method. American Journal of Clinical Pathology, 45:493-496.

Beyene, T. and Tesega, B. 2014. L'usage de médicaments vétérinaires : son importance pour la santé publique. Journal of Veterinary Medicine and Animal Health, 6(12) : 302-308.

Blaak, H., Lynch, G., Italiaander, R., Hamidjaja, R. A., Schets, F. M. and De Roda Husman, A. M. 2015. Multidrug-Resistant and Extended Spectrum Beta-LactamaseProducing Escherichia coli in Dutch Surface Water and Wastewater. PLoS ONE, 10: e0127752 doi: 10.1371/journal.pone.0127752.

Bonnedahl, J., Drobni, M., Gauthier-Clerc, M., Hernandez, J., Granholm, S., Kayser Y., Melhus, A., Kahlmeter, G., Waldenstrom, J., Johansson, A. and Olsen, B., 2009. Dissemination of Escherichia coli with CTX-M type ESBL between humans and yellow-legged gulls in the south of France. PLOS ONE, 4: e5958. doi: 10.1371/journal.pone.0005958.

Cizman, M. and Plankar, T. S. 2018. Antibiotic consumption and resistance of Gram negative pathogen (Collateral damage). GMS Infectious Diseases, 6 : 1-9. Publised online doi : 10.3205/000040.

Goni-Urriza, M., Capdepuy, M., Arpin, C., Raymond, N., Caumette, P. and Quentin, C. 2000. Impact of an urban effluent on antibiotic resistance of riverine Enterobacteriaceae and Aeromonas spp. Applied of Environmental Microbiology, 6 6: 125-132.

Kummerer, K. 2004. Resistance in the environment. Journal of Antimicrobial Chemother, 54: 311-320.

Martínez-Martínez, L., Eliecer, C. M., Manuel Rodríguez-Martínez, J., Calvo, J. and Pascual, A. 2008. Plasmid-mediated quinolone resistance. Expert Review of Anti-infective Therapy, 6: 685 -711.

Meyer, E., Gastmeier, P., Déjà, M. and Schwab, F. 2013. Consommation d'antibiotiques et résistance : données provenant d'Europe et d'Allemagne. International Journal of Medical Microbiology: 303(6-7) : 388395. doi : 10.1016 / j.ijmm.2013.04.004.

Ouattara, M. B., Guessennd, K. N., Koffi-Nevry, 
R., Koffi, S., Ouattara, G. D., Gbonon, V., Tiekoura, K. B., Faye-Kette, H. and Dosso M. 2014. Evaluation of Drigalski agar supplemented with ceftazidime $(2 \mathrm{mg} / \mathrm{L})$ for the isolation of spectrum betalactamase (ESBL) producing Enterobacteria. African Journal of Microbiology Research, 8(29) : 2758-2765.

Paterson, D. L. 2006. Resistance in gram-negative bacteria: Enterobacteriaceae. American Journal of Infection Control, 34(5-1): 6473.

Rizzo, L., Manaia, C., Merlin, C., Schwartz, T., Dagot, C., Ploy M.C., Michael, I. and Fatta-Kassinos, D. 2013. Urban Wastewater Treatment Plants as Hotspots for Antibiotic Resistant Bacteria and Genes Spread into the Environment: A Review. Science of the Total Environment, 447 : 345-360. doi: 10.1016/j.scitotenv.2013.01.032.

Schwartz, T., Kohnen, W., Jansen, B. and Etobst, U. 2003. Detection of antibiotic resistant bacteria and their resistance genes in wastewater, surface water, and drinking water biofilms. FEMS Microbiology Ecology, 43(3): 325-335.

Tennstedt, T., Szczepanowski, R., Braun, S., Puhler, A. and Schluter, A. 2003. Occurrence of integron-associated resistance gene cassettes located on antibiotic resistance plasmids isolated from a wastewater treatment plant. FEMS Microbiology Ecology, 45: 239-252.

Tumeo, E., Gbaguidi-Haore, H., Patry, I., Bertrand, X., Thouverez, M. and Talon, D. 2008. Are antibiotic-resistant Pseudomonas aeruginosa isolated from hospitalized patients recovered in the hospital effluents? International Journal of Hygiene and Environmental Health, 211: 200-204.

Winokur, P., Canton, L. R., Casellas, R. J. M. and Legakis, N., 2001. Variations in the prevalence of strains expressing an extended-spectrum beta-lactamase phenotype and characterization of isolates from Europe, the Americas, and the Western Pacific region. Clinical Infection Disease, 32 (Suppl 2): S94-103.

Zarfel, G., Lipp, M., Gurtl, E., Folli, B., Baumert, R. and Kittinger, C. 2017. Troubled Water under the Bridge: Screening of River Mur Water Reveals Dominance of CTX-M Harboring Escherichia coli and for the First Time an Environmental VIM-1 Producer in Austria. Science of the Total Environment, 593-594 : 399-405. doi: 10.1016/j.scitotenv.2017.03.138.

Zhang, H., Gao, Y. and Chang, W. 2016. Comparison of Extended-Spectrum BetaLactamase-Producing Escherichia coli Isolates from Drinking Well Water and Pit Latrine Wastewater in a Rural Area of China. BioMed Research International, Volume 2016. ID 4343564. doi : $10.1155 / 2016 / 4343564$.

Zurfluh, K., Hachler, H., Nuesch-Inderbinen, M. and Stephan, R. 2013. Characteristics of Extended-Spectrum Beta-Lactamase- and Carbapenemase-Producing Enterobacteriaceae Isolates from Rivers and Lakes in Switzerland. Applied and Environmental Microbiology, 79 : 30213026. doi: 10.1128/AEM.00054-13.

\section{How to cite this article:}

Wognin Affou Séraphin, Ouattara Mohamed Baguy, N'goran Kouamé Edouard and Guessennd Kouadio Nathalie. 2021. Survey of Multi-Resistant Bacteria in Waste Water from the Yopougon Hospital and University Center (CHU), The Abattoir of Port-Bouët and the Lagoon Bays of the City of Abidjan (Côte d'Ivoire). Int.J.Curr.Microbiol.App.Sci. 10(05): 01-09. doi: https://doi.org/10.20546/ijcmas.2021.1005.001 